\title{
Transformation the Meaning of Learning for Millennial Generation on Digital Era
}

\author{
https://doi.org/10.3991/ijim.v14i12.15579 \\ Hardika ( $\left.{ }^{\bowtie}\right)$, Eny Nur Aisyah, Kukuh Miroso Raharjo, Dila Umnia Soraya \\ Universitas Negeri Malang, Malang, Indonesia \\ hardika.fip@um.ac.id
}

\begin{abstract}
This study aims to uncover and describe the transformation of the meaning of learning at the millennial generation mindset. The research approach used is a qualitative research method through a naturalistic phenomenological design. The research subjects consisted of 80 students at the State University which consisted of 3 groups of students from 7 faculties whose average age was 19-24 years: 1) active in student organizations (Ormawa), 2) active in Student Activity Units (UKM) ), and 3) students who are not active at all only attend lecture activities. The data comes from the results of interviews and observations that are analyzed through the stages of synthesis and selection of data, data display, data verification and conclusion, then tested its reliability through cross-checking data sources, comparison of results of literature review, extension of research time, academic feasibility audits through experts, and confirmation to the data source about the accuracy of the meaning of information. The results of this study provide an understanding that there is a transformation of the meaning of learning in the mindset of the millennial generation which is based on changes in students' self as learners and the learning transformation environment in higher education that can support changes in learning outcomes. Changes in students' self as learners in the form of: 1) Self Change, Self Experience, Creativity, motivation, orientation, maturation. A learning transformation environment in higher education that can support changes in learning outcomes, in the form of: 1) Innovation, 2) technology-based, 3) creative and 4) positive condition
\end{abstract}

Keywords - Transformation, The Meaning of Learning, Millennial Generation.

\section{$1 \quad$ Introduction}

The 4.0 industrial revolution that is now happening results in massive changes worldwide. According to Klaus Martin Schwab (2017), these changes include how to live, work and relate to one another, especially at the exponential speed [1]. In the era of the industrial revolution, 4.0 presents new jobs, new professions and some unlimited innovation through IoT. Based on the results of Mc. Kinsey Global Institute research in 2017, in 2030400 to 800 million people must find new jobs because they are replaced by machines[2]. The Minister for Indonesian National Development Planning (Bambang P.S. Brodjonegoro; 2018) has the same opinion; in the industrial 
revolution 4.0, Indonesia will lose 50 million opportunities for its people to work. But it also does not close the projected development of digital economic innovation by increasing efficiency and benefiting Indonesia (Minister of Industry Airlangga Hartarto)[3].

These trends in automation and exchange of data, including cyber-physical systems, internet of things (IoT), cloud computing and cognitive computing are different challenges for millennial learners ("The Fourth Industrial Revolution, by Klaus Schwab," n.d.). Millennial learners are a generation that has different characteristics from its predecessors, they are a generation that has a unique mindset and pattern of action, as well as expectations and life outcomes to be achieved, as well as different learning acceleration. Learning abilities and skills that are in line with the needs of the industrial era 4.0 must be had by them to be able to compete and compete[4]. Answering the pattern of learning interactions that are now being carried out among learners through social media including whatshap and MOOCs. The interaction is carried out through group participation, a collaboration involving peer-topeer and peer-to-instructor interactions[5].

The changes from the meaning of learning that so far have only been based on academic numerical orientation are no longer expected and are always the main goal of millennial learners. The meaning of learning for them participates in changing according to the demands of the environment and the necessities of life. Learning must further inspire the millennial generation that currently exists at a high level of education in order to be able to rise up and be motivated to increase the capacity to manage themselves and the environment in which they live, not just fulfilling intellectual capacity. The teacher must make specific references and emphasize the value of responsibility for students as professionals according to their area of expertise[6].

Indonesia as one of the developing countries in the world which are currently ranked 32nd in the IMD World Competitiveness Ranking 2019, has approximately 2,141 institutions of higher education. One of them is Malang State University as one of the 19th best universities in Indonesia (Kemenristekdikti Press Release Number: 147 / SP / HM / BKKP / VIII / 2019 [7], which has the motto of The Learning University and has life-based learning as its characteristic, is one form of response from the direction of welcoming the industry 4.0 revolution which is oriented to the process and efforts of self-learning participants who are self-learning and self-change by optimizing the ability and capacity of oneself and environmental resources[8]. Changes in the meaning of learning in the mindset of millennial learners in the higher education environment will result in changes in mindset and action patterns in the climate and learning environment to answer the challenges of the times

\section{Research Methodology: Data and Sample Size}

It should be understood that this research uses a qualitative approach, which aims to reveal and describe the actual situation based on facts that occur in the field. Sociocultural aspects and all the characteristics that are inherent and influence the behav- 
iour of research subjects will be examined in-depth, grounded and focused. The research design used in this study is naturalistic phenomenology. Naturalistic phenomenology was chosen because the purpose of this research is to reveal the symptoms of changes that occur in society through the opinions of subjects about things that are understood related to the phenomena under study and are naturalistic, deep and comprehensive.

The research subjects consisted of 80 students at the State University which consisted of 3 groups of students from 7 faculties who were on average 19-24 years of age: 1) active in student organizations (Ormawa), 2) active in Student Activity Units (UKM) ), and 3) students who are not active at all only attend lecture activities. A description of the informant's profile in this study is listed in Table. Profile Research Subject Based on Their Faculties and Activities at Universitas Negeri Malang.

Table 1. Profile Research Subject Based on Their Faculties and Activities at Universitas Negeri Malang

\begin{tabular}{|c|c|c|c|}
\hline \multirow[t]{2}{*}{ Faculty } & \multicolumn{3}{|c|}{$\begin{array}{c}\text { Profile dan Number of Informans Based onTheir faculty and Activi- } \\
\text { ties }\end{array}$} \\
\hline & $\boldsymbol{U K M}$ & Ormawa & Un extra organization activity \\
\hline Faculty of Education & 3 & 3 & 4 \\
\hline Faculty of Economic & 4 & 3 & 3 \\
\hline Faculty of Tehnic & 3 & 3 & 4 \\
\hline Faculty of Math and Sciene & 3 & 4 & 3 \\
\hline Faculty of Letters & 3 & 3 & 4 \\
\hline Faculty of Social & 3 & 3 & 3 \\
\hline Faculty of Sport Science & 3 & 4 & 3 \\
\hline \begin{tabular}{|l|} 
Faculty of Psychology \\
\end{tabular} & 4 & 3 & 3 \\
\hline Total & 27 & 26 & 27 \\
\hline
\end{tabular}

The data comes from the results of interviews and observations that are analyzed through the stages of synthesis and selection of data, data display, data verification and conclusion, then tested its reliability through cross-checking data sources, comparison of results of literature review, extension of research time, academic feasibility audits through experts, and confirmation to the data source about the accuracy of the meaning of information

\section{$3 \quad$ Findings and Discussion}

Millennials who are currently students at the State University of Malang, apparently have different learning meanings in the learning process that they do every day in the tertiary education environment. In their view the principle of learning is an activity of democratic self-actualization process, using information technology devices, comfortable conditions, there are no exams or tests, curricula that are in accordance with the conditions of developing societies, gaining appreciation for the achievers, knowledge-oriented towards acceptance in the working environment, stick to applicable values and norms, and prioritize the abilities and skills of students[9]. 
Learning for the millennials student also have the function of socializing, practising self-actualization, forming personality, working together to solve problems, increasing self-confidence. In the learning process, students expect to prioritize the transfer of learning, not just the transfer of knowledge. Educators become a companion every time when the learning process and also as a learning motivator, as well as learning resources that are easily accessible[10]. The learning process is a process carried out to be able to explore experiences from oneself, both through the use of social media and others, so that through the learning process various knowledge will be obtained to enrich the learning outcomes they expect. So the learning process traversed by students of the present era is not limited to time, space and conditions. The learning process can be done anywhere and anytime.

Changes in self and behaviour for the better are one of the purposes of today's students from the learning outcomes they want to obtain. Changes in behaviour intended are positive things. So that learning activities are also goals so that the results should have a positive connotation. Balancing the active behaviour of a person who is successful in acquiring his knowledge must be accompanied by a tangible manifestation of a work that has a better impact so that the learning process has more meaning because learning activities that aim at a better life change[11].

Learning for current generation students strives to form positive attitudes both for themselves and for others[9]. Knowledge and information are not only obtained from teaching but also knowledge from experience. The balance of learning based on direct experience is something that is highly anticipated for millennials. Learning activities that synergize in the physical, cognitive and affective processing of students simultaneously make the learning experience very valuable for the success of students to obtain life skills in their future survival.

As a person who continues to develop and evolve, students have perceptions related to the meaning of learning. Based on the grouping of data categories the results of the meaning of learning transformation in millennial generation perceptions are categorized in 2 types of data in the form of; 1) learning transformation for students' selftransformation as the learner, and 2) learning transformation environment in higher education that is expected to support changes in students. The Figure 1 shown a graphic description of the results of data analysis that have been obtained. 


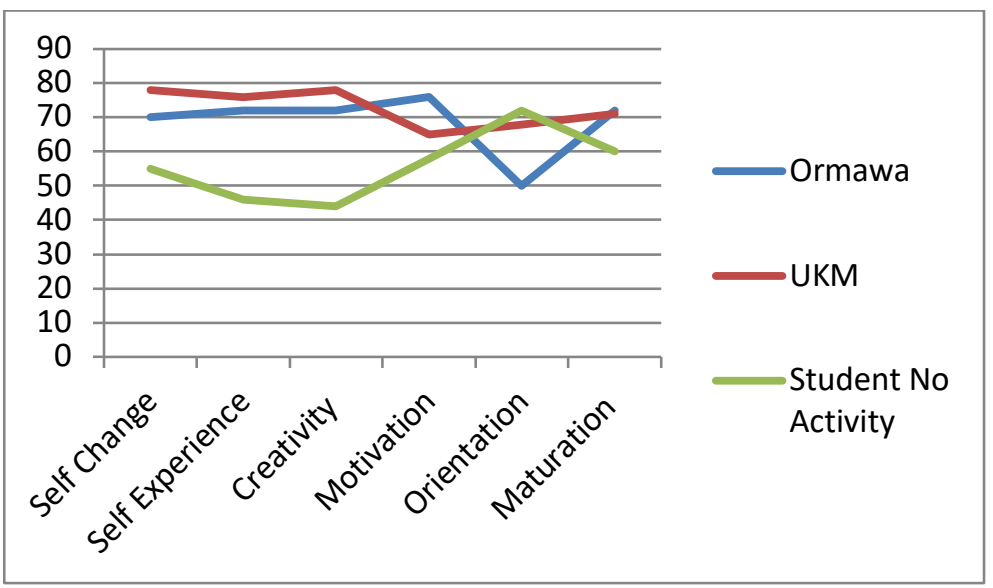

Fig. 1. Line Graph Learning Mindset of Milenial Generation Based on Personality

Based on the figure 1 shown that Students who are active in Ormawa and UKM have the perception that learning related to themselves is the realization of changes in behavior, creativity, motivation, and maturity in attitude. Learning orientation is not a priority for students who are active in Ormawa in conducting learning activities. Students who are not active in Ormawa and UKM, have a learning meaning that emphasizes learning orientation, not creativity and maturity in attitude. Self-experience is something that is in common in the perception of the meaning of learning related to their self by the three groups of students. Learning activities that have an orientation of achievement from what previously could not be able to, requires a learning process to achieve results through an exercise, perseverance, and high concentration

One of the supporting activities of millennial generation is the supportive and appropriate environment. The meaning of transformation in learning related to the learning environment, the results obtained are; 1) students who are active in Ormawa and UKM have a positive, innovative and creative climate perception based on technology that is a learning environment that can support their learning activities. Except students who are active in UKM, they feel they do not need innovation in the learning process. 2) Based on the learning environment of students who are not active in Ormawa and SMEs, tends to like innovation in learning, not just a positive climate, and 3) All three categories of students have the same perception about the meaning of learning related to the environment, namely technology-based. Following is the explanation of the results of the transformation of the meaning of learning in millennial generation related to the learning environment 


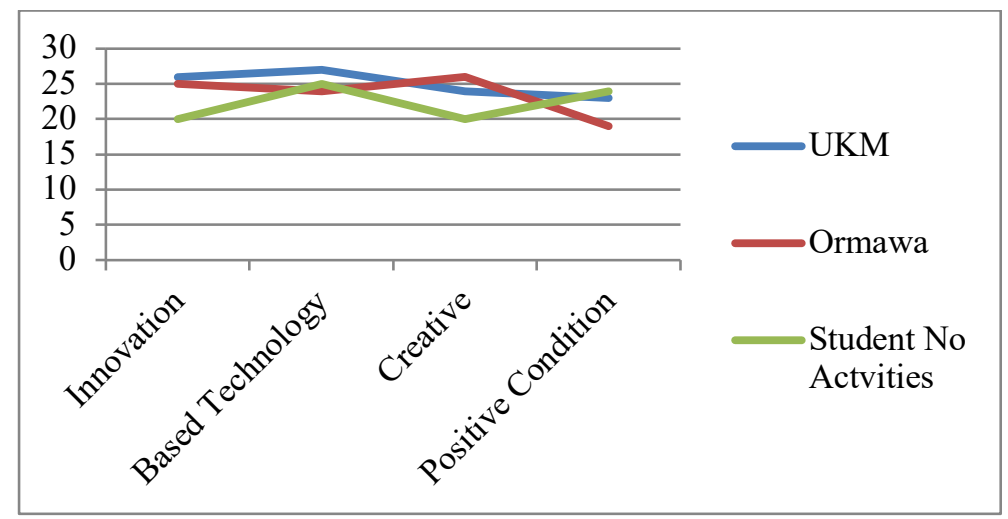

Fig. 2. Line Graph: Meaning of Learning Based on Environment Student

Based on Figure 2 known that an environment that is conducive to innovation that occurs in a stimulant-based technology that is full of creativity and prioritizes comfort and safety during learning becomes a supporting facility in good learning transformation for millennial generations to study in higher education. Environmental infrastructure supporting the transformation of millennial generation learning in higher education in the form of an environment that prioritizes comfort and safety during learning with a variety of innovations that occur stimulously based on technology. Learning activities are specifically learning through the use of mobile technology that is equipped with active social interaction tools.

Learning perception of the millennial generation is a form of perspective who representative self and environment assumption. On Themselves, the considerations about behaviour changes, experience, creativity, motivation, work orientation, and maturity are the point of how the learning paradigm in their views must be balanced with the assumptions of the environment that take almost role to achieve millennial outcomes learning.

According to the theory of individual learning, learning can be interpreted as a learner activity to process information which optimal using learning resources and media[12]. The use of active technology in the learning process of college students has an important role in developing learning creativity and its ability to adapt to various forms of global information[13]. The ease of access to receiving information that can be done anytime and anywhere and by anyone is an added value which is the main orientation of the millennial generation choosing social technology as their current source of learning[14]. This has become a form of success in learning independence for students today. The extent of achievements in utilizing technology in this learning process, by the findings of Nuur Wachid Abdul Majid who stated that elearning provides very broad benefits for easy access to working and learning communities [15].

Wedemeyer said that the selection of learning resources and media should be aimed at (a) freeing students from regular learning style, (b) open learning opportunities appropriate with the ability, and (c) construct instructional style that guides students to implement self-directed learning. According to the perspective of humanistic 
psychology, independent learning is a form of self-directing learning that allows students to think and practice learning [16]. Independent learning is one of the learning patterns which is required in adult education ("Preview of Independent learning in higher education[17]. Others, face-to-face learning in the classroom, students have to do independent learning activities to do the learning materials in the curriculum. The obligation that must be done by educators about independent learning is to provide enough space and time or learning area so that students can learn well as their needs and opportunities[18].

The learning strategy is a guide for the development of the learning process. Learning strategies can be interpreted as the implementation of learning styles or models to process the information to be more meaningful and able to overcome various problems or learning difficulties [19]. Genetically a person's style in processing information can be divided into 2 groups, the holistic group, and the serialist group. The holistic group prefers to follow comprehensive learning procedures that lead to complex hypotheses, while the serialist group (parties) prefer to follow the learning style step by step. The Educators are required to be able to apply both styles with the aim of (a) that learning material can be mastered thoroughly by students; (b) many things that can inhibit the learning process can be overcome, and (c) learning pathologies such as globetrotting and reading which only focus on detail without being able to uncover and raise the meaning of the content can be minimized [20].

Self-concept also takes a role to form and save learning messages (retention) and determine a person's endurance to the pressure and dynamics of information from outside himself [21]. Kadarko's research on students of St. Louis in the Philippines found that a correct perception of the academic environment would produce a more stable self-concept, and the maturity of self-concept would be the beginning of a student's ability to keep consistent learning, translate experiences positively and build trust to hang hopes for the goals. This research found that learning problems must be solved by a variety of approaches concerning the aim of learning, personal and social factors, learning styles, selected learning models, the ability to provide the effective understanding and arouse learning enthusiasm[22].

In connection with transformative learning that inspires students to be more creative, learning can be interpreted as a human activity to process information critically by utilizing resources and community learning media optimally. Depend on Wedemeyer in (Kadarko, 2006) resources and learning media used in learning process must aim to give students creativity in their learning and be able to open opportunities for participants to learn[16]. Learning must also be able to build self-directed of good education interaction, because with this pattern there will be an increase in the cognitive activity of participants learning independently[8]. The development of cognitive activity will be influenced by learning behaviour patterns as the level maturity of the learning participants.

The development of inspiring learning models must provide broadest opportunities for students to actualize their interests and abilities as well as their creativity. Learning strategies should focus on more aspects of student empowerment toward independence and creativity in overcoming self and environmental problems [23]. Kindevatter said learning participants must be given access to get learning resources, 
stronger bargaining power, choices to decide attitudes, the status of self-concept, increased critical attitude, and recognition of self-existence so they have high selfconfidence [24]. World Bank Group (2002)emphasizes, the efforts to form productive learning behaviours, learning participants as learning subjects need to be allowed to adapt to the situation and potency in their environment [25]. The service quality and student involvement in learning have a significant influence on learning achievement [26].

From some opinions, it can be concluded that the success of learning is not exclusively determined by the intelligence of educators and students, but also influenced by the accuracy in choosing and implementing learning models. The essence of learning is place educators not in the teacher's capacity, but are learning facilitators who function as (1) catalysts (accelerating the process of learning), (2) resources linkers (connecting various learning resources), (3) process helper (helper of learning process), and (4) solution helper ("Cultures of Teaching and Educational Change | SpringerLink," nd). In this context, learning is a process of awareness and empowerment of learning participants in developing their potential change environment as an effort to develop self-awareness[27]. According to Gagne, several types of learning capabilities can be learned by the person to improve life performance, they are intellectual skills, verbal information, cognitive strategies, motor skills, and attitudes[28].

Here is one of the figur 3. step of facilitation models for transformative learning in Schwarz's opinion.

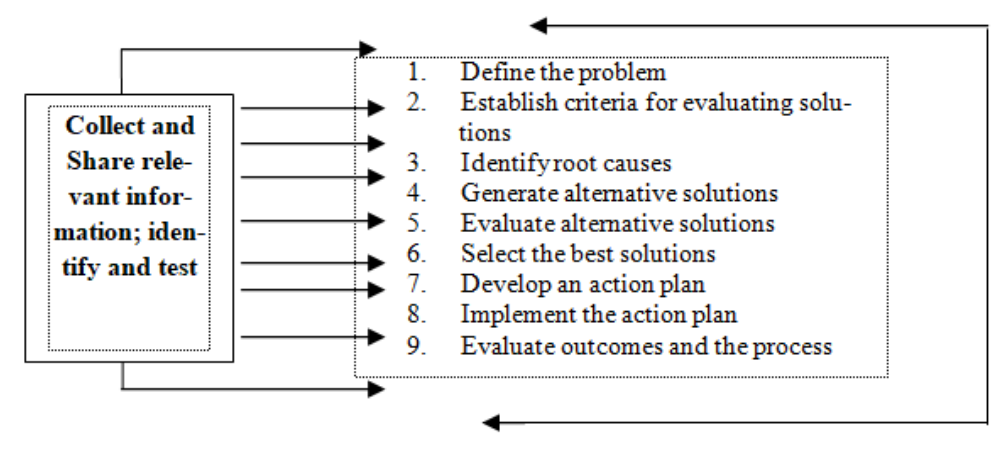

Fig. 3. Source: Schwarz's[29]

As the figure 3 shown that considering lecture process is not only structured in the classroom, but also independent learning outside the classroom, this model is very appropriate to be implemented in groups with independent learning or learning outside the classroom including study tour [30]. The results of this activity, then are discussed in the classroom by a multi-directional dialogue process and the lecturer acts as a facilitator. Facilitators as individuals who assisting or managing the process of exchanging information between students [31]. A facilitator is an individual whose job is to help to manage a process of information exchange[32]. While an expert's role 
is to offer advice, particularly about the content of a discussion, the facilitator's role is to help with HOW the discussion is proceeding.

According to Havelock in the facilitation process, the facilitator must understand the group system, the target character and live up to the problems. Besides that, the facilitator must understand the organizational system and client system that is being faced for a change[33]. According to Carl Rogers, in the world of education need three attitudes that must be done by the facilitator, 1) understanding the reality of himself as a facilitator, (2) accepting, appreciating, and believing in students' opinions, and (3) having an understanding or empathy attitude towards students [34]. The characteristics of facilitative educators according to the research of Aspy and Roebuck's in 1975 in Benedict are they are able to respond to participants' learning feelings, use the ideas of participants to do learning interactions, dialogue and discuss with learning participants, respect learning participants, adjust to the needs of participants learn, and be empathetic [35].

\section{Conclusion}

The results of this study provide an understanding that there is a transformation of the meaning of learning in the mindset of the millennial generation which is based on changes in students' self as learners and the learning transformation environment in higher education that can support changes in learning outcomes. Changes in students' self as learners in the form of: 1) Self Change, Self Experience, Creativity, motivation, orientation, maturation. A learning transformation environment in higher education that can support changes in learning outcomes, in the form of: 1) Innovation, 2) technology-based, 3) creative and 4) positive condition

Learning perception of the millennial generation is a form of perspective who representative self and environment assumption. On Themselves, the considerations about behaviour changes, experience, creativity, motivation, work orientation, and maturity are the point of how the learning paradigm in their views must be balanced with the assumptions of the environment that take almost role to achieve millennial outcomes learning.

In connection with transformative learning that inspires students to be more creative, learning can be interpreted as a human activity to process information critically by utilizing resources and community learning media optimally. Proper learning models and awareness the role of lecturers beside to teaching also includes facilitating students to do exploration and self-actualization of their potential and the utilization of environmental potential as a source and learning media is the key to the success of learning outcomes that expected by millennial generation in learning in higher education. Changes and achievements as the needs of the era must be an orientation in carrying out the role of a facilitator model to understand the group system, the target character and live the problems being faced 


\section{Acknowledgement}

We wish to take this opportunity to thank all those who have contributed in one way or the other toward the completion of this qualitative research exploration.

\section{References}

[1] "The Fourth Industrial Revolution, by Klaus Schwab," World Economic Forum. https://www.weforum.org/about/the-fourth-industrial-revolution-by-klaus-schwab/ (accessed Aug. 25, 2019). https://doi.org/10.1080/13547860.2019.1686320

[2] 1615 L. St NW, Suite 800Washington, and D. 20036USA202-419-4300 | M.-857-8562 | F.-419-4372 | M. Inquiries, "Experts on the Future of Work, Jobs Training and Skills," Pew Research Center: Internet, Science \& Tech, May 03, 2017. https://www.pewresearch.org/internet/2017/05/03/the-future-of-jobs-and-jobs-training/ (accessed Dec. 30, 2019).

[3] G. Post, "Revolusi Industri 4.0: Pengertian, Prinsip, dan Tantangan Generasi Milenial," Maxmanroe.com, Jan. 10, 2019. https://www.maxmanroe.com/revolusi-industri-40.html (accessed Aug. 25, 2019). https://doi.org/10.31227/osf.io/s8gcm

[4] "(16) Improving Student Learning Independence through Transfer of Learning Strategies Hardika |Request PDF,” Research Gate. https://www.researchgate.net/publication/3340 56398 Improving_Student Learning_Independence through_Transfer_of_Learning_Strat egies (accessed Aug. 06, 2019). https://doi.org/10.2991/icet-18.2018.10

[5] E. A. Jackson, "The Use of WhatsApp for Flexible Learning: Its Effectiveness in Supporting Teaching and Learning in Sierra Leone's Higher Education Institutions," Int. J. Adv. Corp. Learn. IJAC, vol. 13, no. 1, pp. 35-47, Mar. 2020. https://doi.org/10.3991/ijac.v13i1. $\underline{11381}$

[6] S. Stelios and A. Christodoulou, "Teaching Professional Integrity: An Empirical Study on Engineering Students," Int. J. Eng. Pedagogy IJEP, vol. 10, no. 3, pp. 98-105, May 2020. https://doi.org/10.3991/ijep.v10i3.12013

[7] "Menristekdikti Umumkan Klasterisasi Perguruan Tinggi Indonesia 2019, Fokuskan Hasil dari Perguruan Tinggi - Ristekdikti.” https://www.ristekdikti.go.id/kabar/menristekdiktiumumkan-klasterisasi-perguruan-tinggi-indonesia-2019-fokuskan-hasil-dari-perguruantinggi/ (accessed Aug. 30, 2019). https://doi.org/10.31227/osf.io/zfm34

[8] S. Fan, H. Tian, and C. Sengul, "Self-optimization of coverage and capacity based on a fuzzy neural network with cooperative reinforcement learning," EURASIP J. Wirel. Commun. Netw., vol. 2014, no. 1, p. 57, Apr. 2014, https://doi.org/10.1186/1687-1499-2014$\underline{57 .}$

[9] J. Záhorec, A. Nagyová, and A. Hašková, "Teachers' Attitudes to Incorporation Digital Means in Teaching Process in Relation to the Subjects they Teach," Int. J. Eng. Pedagogy IJEP, vol. 9, no. 4, pp. 100-120, Aug. 2019. https://doi.org/10.3991/ijep.v9i4.11064

[10] É. M. Granjeiro, "Research-based teaching-learning method: a strategy to motivate and engage students in human physiology classes," Adv. Physiol. Educ., vol. 43, no. 4, pp. 553-556, Nov. 2019, https://doi.org/10.1152/advan.00034.2019.

[11] M. Combi, "Cultures and Technology: An Analysis of Some of the Changes in ProgressDigital, Global and Local Culture," in Cultural Heritage in a Changing World, K. J. Borowiecki, N. Forbes, and A. Fresa, Eds. Cham: Springer International Publishing, 2016, pp. 3-15. https://doi.org/10.1007/978-3-319-29544-2 1 
[12] N. Schwarz, "Individualism and Collectivism," Journal of Consumer Psychology, Jan. 01, 2006. https://onlinelibrary.wiley.com/doi/abs/10.1207/s15327663jep1604_2(accessed Aug. $25,2019)$.

[13] A. Blilat and A. Ibriz, "Design and Implementation of P2P Based Mobile App for Collaborative Learning in Higher Education,” Int. J. Interact. Mob. Technol. IJIM, vol. 14, no. 07, pp. 115-132, May 2020. https://doi.org/10.3991/ijim.v14i07.13167

[14] K. F. Hashim, A. Rashid, and S. Atalla, "Social Media for Teaching and Learning within Higher Education Institution: A Bibliometric Analysis of the Literature (2008-2018)," Int. J. Interact. Mob. Technol. IJIM, vol. 12, no. 7, pp. 4-19, Nov. 2018. https://doi.org/10.39 91/ijim.v12i7.9634

[15] N. W. A. Majid and S. Fuada, "E-Learning for Society: A Great Potential to Implement Education for All (EFA) Movement in Indonesia," Int. J. Interact. Mob. Technol. IJIM, vol. 14, no. 02, pp. 250-258, Feb. 2020. https://doi.org/10.3991/ijim.v14i02.11363

[16] "Charles Wedemeyer's Theory of Independent Study by Montrice Lucas on Prezi." https://prezi.com/ptk7gvmuzff8/charles-wedemeyers-theory-of-independentstudy/(accessed Aug. 28, 2019).

[17] "Preview of Independent learning in higher education. [WorldCat.org]." https://www.worldcat.org/title/independent-learning-in-highereducation/oclc/299387752/viewport(accessed Aug. 28, 2019).

[18] "(PDF) Styles of learning and approaches to studying in higher education." https://www.researchgate.net/publication/238183060_Styles of learning and approaches to studying in higher education (accessed Aug. 28, 2019). https://doi.org/10.1108/036 $\underline{84920110391823}$

[19] "The increasing relevance of Pask's work to modern information seeking and use | Emerald Insight." https://www.emerald.com/insight/content/doi/10.1108/EUM0000000005694/ full/html?full $\mathrm{Sc}=1 \&$ full $\mathrm{Sc}=1 \& \mathrm{mbSc}=1$ (accessed Aug. 28, 2019).

[20] "Information-Processing Alternatives to Holistic Perception: Identifying the Mechanisms of Secondary-Level Holism Within a Categorization Paradigm.” https://www.ncbi.nlm.nih.gov/pmc/articles/PMC2933083/(accessed Aug. 28, 2019).

[21] M. Bong and E. M. Skaalvik, "Academic Self-Concept and Self-Efficacy: How Different Are They Really?,” Educ. Psychol. Rev., vol. 15, no. 1, pp. 1-40, Mar. 2003, doi: 10.1023/A:1021302408382.

[22] "Consistency in Learning Strategies on JSTOR." https://www.jstor.org/stable/3446542? $\underline{\text { Search=yes\&resultItemClick=true\&searchText }=\text { consistency\&searchText=learning\&search }}$ Uri=\%2Faction $\% 2$ FdoBasicSearch $\% 3$ FQuery $\% 3$ Dconsistency $\% 2$ Blearning $\% 26 \mathrm{amp} \% 3 \mathrm{Bf}$

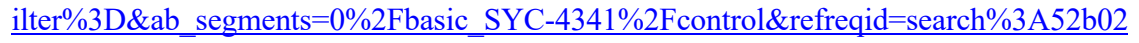
6859679a131d7be4af91f249f97\&seq=1\#page scan tab_contents (accessed Aug. 28, 2019).

[23] "Freire and the millennials: Revisiting the triangle of transformation." http://www.rizomafreireano.org/freire-and-the-22(accessed Aug. 28, 2019).

[24] S. Kindervatter, "Nonformal education as an empowering process: with case studies from Indonesia and Thailand.," p. 297.

[25] "The World Economic Forum.” https://www.weforum.org/ (accessed Aug. 25, 2019).

[26] A. Al-Azawei and M. A. A. Al-Masoudy, "Predicting Learners' Performance in Virtual Learning Environment (VLE) based on Demographic, Behavioral and Engagement Antecedents," Int. J. Emerg. Technol. Learn. IJET, vol. 15, no. 09, pp. 60-75, May 2020. https://doi.org/10.3991/ijet.v15i09.12691

[27] C. McGrail Johnston, "Paulo Freire: Reading, Knowledge and the Emotional Body," Jan. 2016. 
[28] "Conditions of Learning: Amazon.co.uk: Robert M. Gagne: Books." https://www.amazon.co.uk/Conditions-Learning-Robert-M-Gagne/dp/0039100693 （accessed Aug. 06, 2019).

[29] "Developing a learning progression for scientific modeling: Making scientific modeling accessible and meaningful for learners - Schwarz - 2009 - Journal of Research in Science Teaching - Wiley Online Library." https://onlinelibrary.wiley.com /doi/abs/10.1002/tea.20311(accessed Aug. 28, 2019). https://doi.org/10.1002/tea.20311

[30] "Deepening Learning and Inspiring Rigor: Bridging Academic and Experiential Learning Using a Host Country Approach to a Study Tour - Susan Orpett Long, Yemi Susan Akande,R.W.Purdy,KeikoNakano,2010."'https://journals.sagepub.com/doi/abs/ 10.1177/1028315308327952? casa token=sdiCM816K28AAAAA:q lvqu4gKXfR79OxhT Ipu7eD5A9bHau6PuhWKARuHWVh9zauuINz1h48PDXySfH JnuTeqIa20KAMg (accessed Aug. 28, 2019). https://doi.org/10.1177/1028315308327952

[31] A. Rumney, "Facilitating Learning," 2019, pp. 1-21.

[32] H. Hardika, E. N. Aisyah, and I. Gunawan, "Facilitative Learning to Improve Student Learning Creativity," presented at the 3rd International Conference on Educational Management and Administration (CoEMA 2018), Oct. 2018, https://doi.org/10.2991/coema18.2018 .44 .

[33] H. Hardika, E. Nur Aisyah, and I. Gunawan, "Facilitative Learning to Improve Student Learning Creativity," in Proceedings of the 3rd International Conference on Educational Management and Administration (CoEMA 2018), Malang, Indonesia, 2018, https://doi.org/10.2991/coema-18.2018.44.

[34] "Carl Rogers | edpsychologists." https://erinspencer.wixsite.com/edpsychologists/carlrogers(accessed Aug. 28, 2019).

[35] R. R. Benedict, "The Facilitative Teacher-Student Relationship and Selected Educational Outcomes," p. 139.

\section{$7 \quad$ Authors}

Hardika is a lecturer in the Non-Normal Education Department Faculty of Education at Universitas Negeri Malang. He is also a member of IEEE Publisher. He is the editor of several journals at Universitas Negeri Malang there is the Journal of Education Faculty of Education and International Research-Based Educational Journal Faculty of Education. He is a reviewer for the Annual International Conference of Education and Training (ICET) and International Conference on Early Childhood and Primary Education Faculty of Education Universitas Negeri Malang. He is also an active member of the Indonesian Non-Normal-Informal Educators Association, Member of the Indonesian Social Education Bachelor Association.

Eny Nur Aisyahis a lecturer in the Childhood Education Department Faculty of Education at Universitas Negeri Malang. She is working also as a consulting Early Childhood Education at Dunia Anak Consultancy. She is a member of the National Association in Early Childhood Education. And also, as a reviewer of Golden Age Journal at Islamic Bandung University.

Kukuh Miroso Raharjo is a lecturer in the Non-Normal Education Department Faculty of Education at Universitas Negeri Malang. He is also an active researcher in the science of informal education. 
Dila Umnia Soraya is a lecturer in the Education Informatics Engineering Departement Faculty of Engineering at Universitas Negeri Malang. She is active in the research development of Mobile OS-based online learning media. She's also a researcher of trans-disciplinary learning with Project-Based Learning Model (PBL) Based on Blended Learning Using Digital Sharing Platform Community.

Article submitted 2020-04-30. Resubmitted 2020-05-19. Final acceptance 2020-05-20. Final version published as submitted by the authors. 